\title{
Lisbon: reading the (post-)colonial city from the nineteenth to the twenty-first century
}

\author{
ELSA PERALTA and NUNO DOMINGOS \\ Centro de Estudos Comparatistas, Faculdade de Letras da Universidade de \\ Lisboa, Alameda da Universidade, 1600-214 Lisboa, Portugal \\ Instituto de Ciências Sociais da Universidade de Lisboa, Av. Prof. Aníbal \\ Bethencourt, 9,1600-089 Lisboa, Portugal
}

\begin{abstract}
The study of the urban experience in Lisbon, the former capital of the Portuguese empire, creates a specific observatory to interpret the colonial process and its post-colonial developments. Following an itinerary from colonial to postcolonial times, this article examines the continuities and discontinuities of Lisbon's urban dynamics linked with Portugal's colonial history through three interlinked processes. First, the material inscription of policies of national identity in the memory space of the city since the late nineteenth century until today. Second, the expansion of a network of economic relations that affected Lisbon's industrial, commercial and urban life. And finally, the development of a system of social and political organization, where spatial distribution and civil and political rights were unequally distributed.
\end{abstract}

Focusing on Lisbon, this article aims to address the continuities between the colonial and the post-colonial periods in the institutions and representations of the city's imperial past. Some of the presumptions in which this article is based can be found in studies about imperial metropolises such as London or Paris. Drawing on studies by, amongst others, Felix Driver and David Gilbert, ${ }^{1}$ the article contributes to a body of scholarship that analyses urban developments in metropolitan centres in close relation with the global institution of modern colonialism at a time when, as Anthony King put it, imperial cities operated as central nodes of world trade and imperialist expansion throughout

${ }^{1}$ D. Gilbert and F. Driver (eds.), Imperial Cities: Landscape, Display and Identity (Manchester, 1999); D. Gilbert and F. Driver, 'Capital and empire: geographies of imperial London', GeoJournal, 51 (2000), 23-32. See also J. Schneer, London 1900: The Imperial Metropolis (London, 1999); D. Sunderland, Financing the Raj: The City of London and Colonial India, 18581940 (London, 2013). 
the nineteenth and twentieth centuries. ${ }^{2}$ This means looking at the imaginative colonial geographies ${ }^{3}$ set in imperial metropolises, the imprint of exotic architectural styles and the building of monuments to celebrate imperial triumphs and deeds. It also means looking at the several ways in which empire produced new social and material arrangements in imperial cities, since the use of peripheral territories for primary production or resource extraction prompted the growth of industrial and commercial urban centres and the emergence of new urban classes. ${ }^{4}$

The social and material imprint of colonialism in metropolitan centres goes far beyond the formal end of colonialism to continue influencing how former imperial centres have been situated in the new local and regional global power arrangements in post-colonial times. Drawing on studies that place the genealogy of contemporary global cities in the power architectures inherited from colonial times, ${ }^{5}$ this article follows the imperial metropolis to the post-imperial city of the global world. Imperial cities operated as centres of power and connection for the complex network of relationships and exchanges which underpins the current world system. ${ }^{6}$ They were important loci of production and circulation of the imperial and modern capitalist culture, thereby contributing greatly to the reproduction of ideological, economic and cultural orders and to the control of populations. These same global processes are facets of the post-colonial experience, from the integration of immigrant populations and their relationship with the state and the labour market to official policies of imperial memory. Global cities are places of consumption, architectural pastiche and gentrification, where nostalgia for empire is frequently reinvented by city marketers for tourists and where ethnicity

2 A. King, Urbanism, Colonialism and the World Economy: Spatial and Cultural Foundations of the World-System (New York, 1990).

${ }^{3}$ F. Driver, 'Imaginative geographies', in P. Cloke, P. Crang and M. Goodwin (eds.), Introducing Human Geographies (London, 2005), 234-48.

${ }^{4}$ For example P. Chopra, 'Refiguring the colonial city: recovering the role of local inhabitants in the construction of colonial Bombay, 1854-1918', Buildings \& Landscapes: Journal of the Vernacular Architecture Forum, 14 (2007), 109-25; P. Chopra, The City and Its Fragments: Colonial Bombay, 1854-1918, vol. II (Berkeley, 2003); S. Chattopadhyay, Representing Calcutta: Modernity, Nationalism, and the Colonial Uncanny (London, 2005); P. Kidambi, The Making of an Indian Metropolis: Colonial Governance and Public Culture in Bombay, 1890-1920 (London, 2016); A. Brown-May, Death, Decency and the Dead-house: The City Morgue in Colonial Melbourne (Victoria, 2004).

${ }^{5}$ A. King, Global Cities: Post-Imperialism and the Internationalization of London (New York, 1990); J.M. Jacobs, Edge of Empire: Postcolonialism and the City (London and New York, 1996); J. Eade, Placing London: From Imperial Capital to Global City (New York, 2001); R. Varma, The Postcolonial City and its Subjects: London, Nairobi, Bombay (London and New York, 2011); M. Matera, Black London: The Imperial Metropolis and Decolonization in the Twentieth Century (Berkeley, 2015).

6 I. Wallerstein, The Modern World-System: Capitalist Agriculture and the Origins of the European World-Economy in the Sixteenth Century (New York, 1976); S. Mintz, Sweetness and Power: The Place of Sugar in Modern History (New York, 1985); S. Beckert, Empire of Cotton: A Global History (New York, 2014). 
is often celebrated, although processes of racialization and racism often remain 'a taboo vestige of colonial and neo-colonial exploitation'.

This article contends that the study of Lisbon's urbanization has to pay much greater attention to the influence exerted by the Portuguese colonial experience. As presented here, Lisbon's case is comparable to other cities whose urbanization was significantly altered by colonialism. Considered to be the capital of a peripheral empire, Lisbon was also the head of an imperial power that through most of the twentieth century was led by a fascist-type regime, whose policies framed the country's colonial nationalism. The transition to democracy did not obliterate the colonial past. Instead, it updated it to accommodate former legacies to new global languages. These are legacies of the colonial 'past as it lives now', as Benoît de L'Estoile has called them, in reference to the 'many ways it is present in Europe today, as it is in formerly colonized countries around the globe'. ${ }^{8}$ While connecting the Portuguese colonial history within the urban history of Lisbon, this article is thus also a contribution to a discussion on the contemporary legacies of Portuguese colonialism.

\section{Imperial space and the politics of national identity}

From the last quarter of the nineteenth century, a transition from an 'informal imperialism' took place, based on the military control over overseas territories, to a more direct domination based on effective occupation. ${ }^{9}$ Conflicting pretensions of different European powers over Africa were at stake, which resulted in the Berlin Conference (1884-85). In this context, internally pressured by the establishment of the liberal regime and the independence of Brazil, which took place in 1822, a new imperial project centred in Africa emerged in Portugal. Along with successive designs of effective colonization, usually with very limited success, radical expressions of imperial nationalism also began to take shape, even during the transition to constitutional monarchy in 1822. Imperial nationalism was especially fostered by the rising Republican party and steadily gained popular support.

Imperial populism reached an exaggerated expression with the 1890 British Ultimatum. Against Portugal's ambition to unite Angola and Mozambique, ${ }^{10}$ Britain forced Lisbon's government to withdraw its forces from the territories of the Chire and Upper Zambezi, on pain of severance of diplomatic relations and attack by the British navy. The Portuguese government promptly withdrew, but the event had a profound impact on the country's political scene. National newspapers described it as

${ }^{7}$ M. Cross and M. Keith (eds.), Racism, the City and the State (London, 1993), 8.

${ }^{8}$ B. de L'Estoile, 'The past as it lives: an anthropology of colonial legacies', Social Anthropology, 16 (2008), 267-79.

${ }_{9}$ G. Barton, Informal Empire and the Rise of One World Culture (Basingstoke, 2014).

10 This ambition was set out in a project known as the 'Pink Map' (Mapa Cor-de-Rosa) submitted at the Berlin Conference (1884-85). 
a tremendous national humiliation and as a plundering of Portugal's historical rights over its inalienable overseas possessions and caused a nationalist uproar, on which the Republican party capitalized heavily, turning out to be a major factor in bringing down the monarchy and establishing the Republic in 1910. These nationalistic demonstrations were loudest in Lisbon. ${ }^{11}$

Portuguese society became embroiled in the African question, which became an issue of national identity. ${ }^{12}$ The colonial empire was enshrined as a key element of Portuguese national history, definitively implanting the myth of the 'sacred heritage' of empire; that is, as a heritage to preserve at any cost. ${ }^{13}$ Without being able to prove the effective occupation and control over the territories Portugal claimed, the Portuguese empire was based on the historical past, on the saga of the maritime discoveries of the fourteenth and fifteenth centuries. Portugal appealed to the legacy of the 'golden age' of national history to assert what was considered by the political and intellectual elites to be the country's legitimate rights in Africa: the Portuguese were not only the first to arrive, but had discovered these territories, too.

In the sphere of colonial policy, the urgency of preserving this 'sacred heritage', with the numerous benefits expected from it, resulted in the organization of military campaigns for the occupation of the African territories, as well as the organization of geographical expeditions to explore the African interior, in response to the general research movement of the Continent carried out by the other European powers. The new conquerors and explorers - Silva Porto, Roberto Ivens, Brito Capelo, Serpa Pinto, António Maria Cardoso, Vítor Cordon, Paiva de Andrada, Alves Roçadas, Paiva Couveiro and, above all, Mouzinho de Albuquerque were converted into national heroes and recognized as the re-founders of the discoveries. The victory in Mozambique over Gungunhana, sovereign of the Vátuas, in the campaigns of 1895 and the subsequent procession through the streets of Lisbon of the defeated king, together with the triumphant and enthusiastic reception of the victorious expeditionary troops, were the definitive reasons for the sanctification of the empire at the end of the nineteenth century.

During this period, which was marked by a wave of patriotic exaltation, the discourses aimed at spreading a national-imperialist ideology multiplied, particularly in the metropolitan capital. It was the 'age of

11 V. Alexandre, 'Nação e império', in F. Bethencourt and K. Chaudhuri (eds.), História da Expansão Portuguesa, vol. IV (Lisbon, 1998), 90-142.

12 F. Bethencourt and D.R. Curto (eds.), A Memória da Nação (Lisbon, 1991); J. Mattoso, A Identidade Nacional (Lisbon, 1998); F. Bethencourt, 'A memória da expansão', in F. Bethencourt and K. Chaudhuri (eds.), História da Expansão Portuguesa, vol. V (Lisbon, 1999), 442-80; L. Cunha, A Nação nas Malhas da sua Identidade: O Estado Novo e a Construção da Identidade Nacional (Porto, 2001).

13 Alexandre, 'Nação e império', 132. 
nationalism ${ }^{\prime 14}$ and Portugal embarked on a number of commemorative and celebratory actions to construct a coherent, homogenizing narrative about Portuguese national identity. ${ }^{15}$ The new imperial mythology was key to this construction. It can be observed in the re-telling of Lisbon's history, with the celebration of iconic monuments and spaces linked with the age of discoveries, the construction of new buildings, the erection of statues, the naming of streets and neighbourhoods, the organization of exhibitions and other symbolic moments of socialization. ${ }^{16}$

The first monumental actions took place with the aim of reconfiguring Lisbon as an 'imperial city'. ${ }^{17}$ The Jerónimos Monastery, strongly associated with the fifteenth-century voyages of overseas expansion, and the Belém area where it is located, became key symbolic markers in the memorial landscape of Lisbon and focal points for many commemorative activities related to empire. ${ }^{18}$ Notwithstanding its symbolic value, by the mid-eighteenth century the monastery was in ruins. Its symbolic appropriation as the great representative of the 'golden age' of the discoveries came about with Liberalism, and thenceforth considered as the unique expression of the 'national style' ${ }^{19}$ Refurbishment work began on the monastery in 1860 and it was classified as a site of national heritage in 1910, the same year the Portuguese Republic was proclaimed. The Jerónimos Monastery was thus definitively enshrined as a symbol of the Portuguese national-imperialist ideology, and has been used at different historical moments by successive regimes as a stage for the most varied civic celebrations of Portuguese nationality.

In 1880, the monastery provided the stage for the celebrations of the tercentenary of Luís Vaz de Camões, author of sixteenth-century epic The Lusiads, the magnum opus of the Portuguese people. The day was celebrated nationally and the city of Lisbon was decked out to follow the civic procession to the Jerónimos Monastery, in whose pantheon were deposited the remains attributed to Camões and to Vasco da Gama, the discoverer of the sea route to India (see Figure 1). Thus began a commemorative cycle dedicated to the glorification of the national epic, ${ }^{20}$ with the aim of recalling the role of the Portuguese in the construction of modern civilization and the nation's place in the sharing of the

${ }^{14}$ H. Kohn, The Idea of Nationalism: A Study in its Origins and Background (New Brunswick, 1961).

15 S. Campos Matos, Conscien̂cia Histórica e Nacionalismo, Portugal Séculos XIX e XX (Lisbon, 2008).

16 Bethencourt, 'A memória da expansão', 442.

17 Driver and Gilbert (eds.), Imperial Cities.

18 E. Peralta, 'A composição de um complexo de memória: O caso de Belém, Lisboa', in N. Domingos and E. Peralta (eds.), Cidade e Império: Dinâmicas Coloniais e Reconfigurações Pós-coloniais (Lisbon, 2013), 361-407.

${ }^{19}$ Bethencourt, 'A memória da expansão', 445.

${ }^{20}$ In addition to the celebrations of 1880 , this commemorative cycle included the fourth centenaries of the birth of Prince Henry (1894), the discovery of the maritime route to India (1898), the discovery of Brazil (1900), the conquest of Ceuta and the anniversaries of Afonso de Albuquerque (1915) and Vasco da Gama (1925), amongst others. 


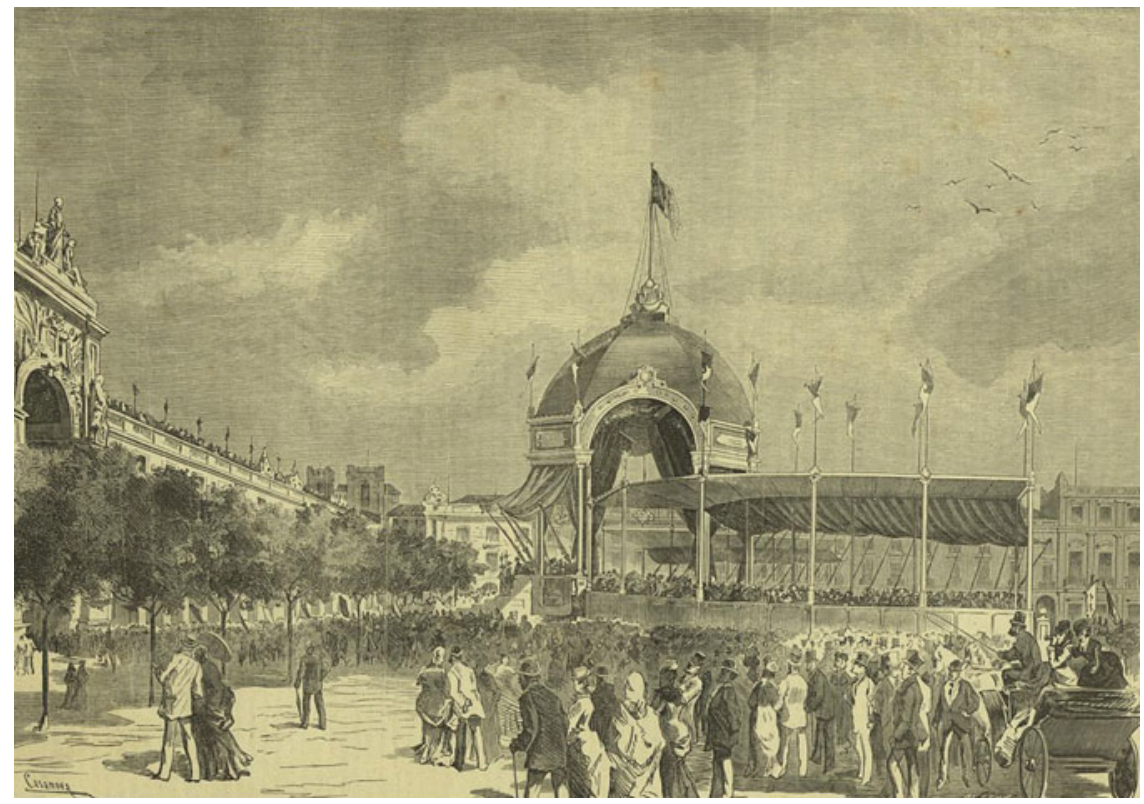

Figure 1: (Colour online) Celebrations of the tercentennial of Luís de Camões (c. 1524-80). The pavilion set up at the Commerce Square, 1 Jul. 1880, in Hemeroteca Digital, O Ocidente: Revista Ilustrada de Portugal e do Estrangeiro, 61, 1 Jul. 1880.

world among European powers, while fostering national 'self-esteem' and enthusiasm for the imperial cause. ${ }^{21}$ Following the model of the civic celebrations of the French Revolution, these commemorations were largely the result of the initiative of republican men whose intention was to highlight the contrast between the decadence of the present and the glories of the past and who urged a new era - that of the Republic - and a break with the past of national decadence, symbolized by the monarchy.

Widely participated by society at large and heavily advertised by the republican press, the main promoter of the celebrations was the Sociedade de Geografia de Lisboa, a private institution founded in 1875 with the aim of developing scientific studies on the colonies and promoting expeditions to Africa to explore the territories. The Society played a key role in inventing the memory of Portuguese expansion and in constructing and disseminating knowledge about overseas colonies, promoting conferences, honouring African explorers and conquerors and supporting historical celebrations. The Colonial and Ethnographic Museum operated in the Society's Lisbon premises from 1892, with a collection related to the history of colonial expansion

${ }^{21}$ Alexandre, 'Nação e império', 117. 
and to the exploration of the African continent. ${ }^{22}$ The Colonial School, which specialized in the training of personnel for the Overseas Public Administration, was also based on the premises of the Society and inaugurated in 1906, under the supervision of the Ministério da Marinha e Ultramar (Ministry of the Navy and Overseas).

The colonial worldview gradually became absorbed into the city space through institutional semantics used in the naming of schools, organizations and institutions, and in the creation of museums with collections dedicated to colonial themes. In 1903, the Portuguese Ethnographic Museum, founded in 1893, was installed in an area of the western wing of the Jerónimos Monastery. Despite being mainly an archaeological museum dedicated to the 'Portuguese Man', it had a Portuguese Overseas Room focusing on the peoples of the colonies, thus including this dimension in the comprehensive representation of Portugal and the 'Portuguese People' that was intended in the monastery, the main stage of Portuguese nationality. ${ }^{23}$

In this period, colonialism also crept into the space of the city in less explicit, yet deliberate, ways. For instance, many exotic species of trees from Brazil, Africa and Asia were planted around the city, constituting a memory, at the same time visible and imperceptible, of the Portuguese expansion in the public spaces of the city that thus acquired a colonial flavour. This purpose was also achieved by the creation of Botanical Gardens, such as the Jardim Botânico de Lisboa (1878), located in the city centre, and Jardim Colonial, established in 1912 in Belém, together with the Colonial Agricultural Museum, created in 1929.

\section{Imaginary geographies}

The memory of the Portuguese expansion and the imaginary geographies of the empire were also perennially inscribed in the symbolic landscape of the city through toponymy and, to a lesser degree, statuary. The first initiative of this type was the inauguration in 1867 of the statue of Camões, placed in a square also baptized with the name of the poet. In the Belém quarter in 1880, the year of the commemoration of the tercentenary of Camões, the Praça D. Vasco da Gama was named after the discoverer of the sea route to India, and in 1901 the statue of Afonso de Albuquerque was erected in a square and garden that were named after the viceroy and governor of India. Moreover, in Belém, Rua Bartolomeu Dias was so named in 1911 as a tribute to the fifteenth-century navigator. Several new streets and squares were named in other areas of the city, either after the maritime expansion or for imperial deeds. For instance, the Streets Capelo, Ivens and Serpa Pinto were baptized in 1885, and in 1890, the year of British

${ }^{22}$ M.I. João, 'Organização da memória', in Bethencourt and Chaudhuri (eds.), História da Expansão Portuguesa, vol. IV, 376-402.

23 João, 'Organização da memória', 392. 
Ultimatum, the Streets António Maria Cardoso, Paiva de Andrada and Vitor Cordon, all of them explorers of the African territories, were also named. The purpose was to 'perpetuate in the memory of the peoples and throughout the generations the names of those who deal with self-denial and value for the greatness of the motherland, and renew today in African lands the brilliance of our best traditions'. ${ }^{24}$

After the military dictatorship in 1926, followed by the establishment of the Estado Novo regime in 1933, the development of a nationalist, integrationist and centralizing colonial policy was accompanied by the promotion of a true 'imperial mystique' related to empire. This mystique was based on the cult of heroes and the idea of a linear historical progression from the founding of the nation to the maritime empire. It permeated the regime's cultural production, from education programmes and school textbooks to exhibitions and scientific conferences. The Agência Geral das Colónias (General Agency of the Colonies), created in 1924, was revitalized by the new regime and swiftly began to create a colonial propaganda apparatus, which included publishing books, producing films and radio broadcasts and organizing courses, seminars and scientific congresses. As in other imperial contexts, colonial propaganda was particularly aimed at an urban audience that supported the emergence of a popular culture linked with mass consumption. ${ }^{25}$

At the same time, there was a monumental glorification of the empire, particularly in Lisbon. In this glorification, the Jerónimos Monastery and the Belém area were again key elements and soon became icons in the dramatization of a mystical imperial discourse. ${ }^{26}$ One of the finest examples of this glorification was the Portuguese World Exhibition held in Belém from June to December 1940, which, as the largest of all propaganda initiatives organized by the regime, received more than 3 million visitors, most of them Portuguese, at a time when Europe was being torn apart by war. ${ }^{27}$ Conceived to mark the anniversary of the founding of the nation in 1143 and the restoration of independence from Spain in 1640, the exhibition included several pavilions and temporary displays dedicated to the empire, as well as a colonial section in the Jardim das Colónias with reconstructed villages and dwellings of the indigenous peoples of the colonies. As in other European imperial contexts, so the metropolitan Portuguese were invited to see Portugal's national community, both metropolitan and overseas, as a whole, thereby mobilizing public

${ }^{24}$ Notice (Edital) of the Lisbon City Council, of 6 Feb. 1890, in Toponimia de Lisboa, https:/ / toponimialisboa.wordpress.com/2015/09/page/2/, accessed 7 Jun. 2017.

25 J. Mackenzie, Imperialism and Popular Culture (Manchester 1986); N. Domingos, 'Cultura popular urbana e configurações imperiais', in M.B. Jerónimo (ed.), O Império Colonial em Questão (Séculos XIX-XX) (Lisbon, 2012), 391-421.

26 Peralta, 'A composição de um complexo de memória imperial'.

27 D. Corkill and J.P. Almeida, 'Commemoration and propaganda in Salazar's Portugal: the Portuguese World exposition of 1940', Journal of Contemporary History, 44 (2009), 381-99. 
support for the empire and promoting the colonial policy of the Estado Novo. ${ }^{28}$

The exhibition left lasting landmarks in the Lisbon landscape. A huge square called Praça do Império (Empire Square), designed by the architect Cottinelli Telmo, was created in front of the Jerónimos Monastery and the Belém area was completely revamped to become a 'public audience of permanent access to the framework of the nation's sacred references' ${ }^{29}$ Accordingly, in Belém and elsewhere in the city streets were named after navigators, protagonists and places related to overseas expansion. With even greater emphasis than in the previous period, during Estado Novo the marks of the empire were embedded in the 'imaginative geographies' of the capital, in an enduring celebration of the imperial feats of national history.

This street naming served as a symbolic response of the regime to the changing international pressures over Portuguese colonial dominions. Following the independence of India in 1947, and in response to the demand for the integration of Portuguese India into the Indian Union, in 1948 the government created in Belém the squares of Damão, Diu and Goa, as well as several other place names linked to the Portuguese expansion, such as Índia and Dom Vasco da Gama Avenues, Streets São Francisco Xavier and Fernão Mendes Pinto and the Square D. Manuel I. In the 1960s, in a context of international pressure for decolonization and the beginning of the colonial wars in Africa, several other toponyms alluding to Portuguese expansion were assigned in the Belém area and the Restelo hill nearby, with several streets named after navigators, missionaries and explorers of the discoveries. The colonial war itself, which began in Angola in 1961, also played out on the toponymic board of Lisbon. In several areas of the city, but particularly in the new suburb of Olivais, streets were named again after soldiers killed in combat overseas, with the caption 'Died Serving the Homeland'. ${ }^{30}$

The colonial theme was also the target of various symbolic investments by the Estado Novo through the opening of a new commemorative cycle related to the discoveries as well as through other acts of public memory. In 1960, for example, the Estado Novo celebrated the fifth centenary of the death of Prince D. Henrique, the main herald of the discoveries, organizing public ceremonies, academic seminars and conferences and publishing books and other printed materials. These were accompanied by other projects, the most relevant of which was the reconstruction of the Monument to the Discoveries in Lisbon. Originally, it was a temporary plaster structure built for the 1940 Portuguese World Exhibition and

28 P.H. Hoffenberg, An Empire on Display: English, Indian, and Australian Exhibitions from the Crystal Palace to the Great War (Berkeley, 2001).

29 J.F. Branco, 'Lugares para o Povo: uma periodização da cultura popular em Portugal', Revista Lusitana (new ser.), 13-14 (1995), 163.

30 In Toponímia de Lisboa, https://toponimialisboa.wordpress.com/2017/02/13/mortosna-guine-e-angola-em-1963-na-toponimia-de-olivais-norte, accessed 7 Jun. 2017. 


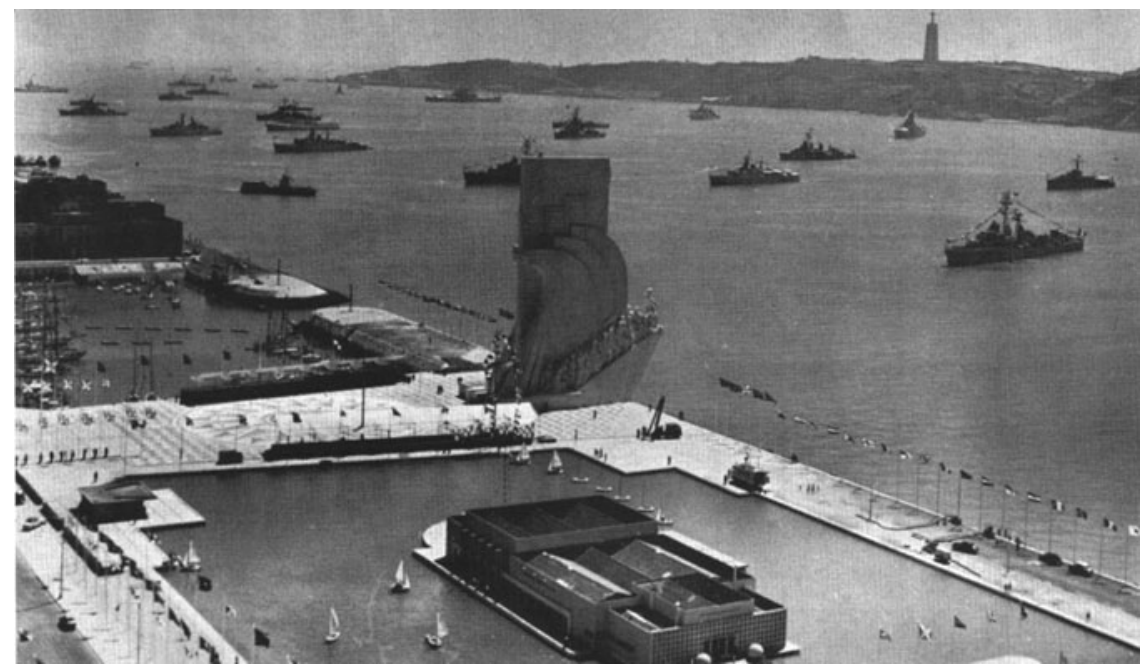

Figure 2: View of the Padrão dos Descobrimentos (Monument to the Discoveries) on the northern bank of the Tagus River estuary, Lisbon, Portugal, at the time of its inauguration, on 9 Aug. 1960. 32 ships of 14 nations were present, in U.S. Navy All Hands Magazine, Oct. 1960, 17.

designed by the architects Cottinelli Telmo and Telmo de Almeida, but it later became permanent, executed in concrete and masonry. As Francisco Bethencourt remarked, it was the 'first monument that symbolically marks, in contemporary times, the "gesta" of expansion, concentrating all the stereotypes that had been mobilized over time by erudite memory and collective memory'. ${ }^{31}$ The monument represents a stylized caravel bow facing the Tagus River, flanked by the sculptures of 32 personages, including the kings, navigators, missionaries, intellectuals and conquerors involved in the saga of the discoveries. In front of them is a larger-sized figure of Prince Henry, who symbolically holds a caravel in his hands (see Figure 2).

Once again, imperial symbolism was used by the colonial government, which appealed to Portugal's seafaring past as arguments to face the outside threats to the integrity of the empire. The Jerónimos Monastery hosted the Museu de Marinha, a museum about Portuguese naval history that opened to the public in 1962 with the 'mission of safeguarding and divulging the Portuguese maritime past'. ${ }^{32}$ At the same time, the Praça do Império was restored, and 30 flower beds were added to represent the coats of arms of the capital cities of Portugal and the provinces of the empire

31 Bethencourt, 'A memória da expansão', 446.

32 http://www.marinha.pt/pt-pt/marinha/cultura/Paginas/Museu-Marinha.aspx, accessed 20 Jan. 2017. 
in alphabetical order, from the province of Angola to Viseu, in northern Portugal. The aim was to reaffirm the unity and indivisibility of the Portuguese empire, achieved through a non-hierarchical representation of the whole Portuguese territory. This was, indeed, the main rhetorical tool used by the Estado Novo against the international anti-colonial policies organized through the United Nations. In this reading, Portugal was a multicontinental nation, which had neither colonies nor nonautonomous territories, but a territory that had the peculiarity of having both metropolitan territories and overseas territories as well, all with an equal status. Therefore, Portugal could not enact the self-determination regime decreed by the United Nations in $1960 .{ }^{33}$

In this period, the rhetoric of the regime came to be strongly expressed in the toponymy of Lisbon, with the establishment in the Olivais neighbourhood in the 1960s and 1970s of toponyms alluding to towns and cities in the Portuguese colonies, such as Avenues Cidade de Lourenço Marques and Cidade de Luanda, and the Streets Cidade de Benguela, Cidade de Bissau, Cidade da Praia, Cidade de Margão and Cidade de Dili. On the outskirts of Lisbon, suburban communities had new streets named after the heroes of the colonial expansion. The Estado Novo thus perpetuated in the imagination of the city the geographies of the Portuguese colonial empire after the outbreak of the colonial wars. As had occurred in 1933, when the names of places in the empire were attributed to the so-called Bairro das Colónias (District of the Colonies) in Lisbon, with the Streets of Angola, Cabo Verde, Príncipe, São Tomé, Macau, Mozambique, Timor, Zaire and Angola, the toponymical inscriptions alluding to the geographies of the empire were perpetuated in the memorial landscape of late twentieth-century Lisbon.

However, while imperial imagination continued to be imprinted on the social geography of Lisbon, the concrete reality of colonial life and populations remained too far removed from the daily life of the metropolis. In the first half of the twentieth century, the African populations introduced in Portugal through slavery since the middle of the fifteenth ${ }^{34}$ century had almost vanished. ${ }^{35}$ Apart from a few individuals, among them students from the African colonies, who gathered between 1944 and 1965 in the Home of the Students of the Empire (Casa dos Estudantes do Império), a facility set up by the Estado Novo to educate the colonial elites, $^{36}$ the presence of people from African or Indian origin in the metropolis was practically non-existent. It was only in the 1960s that the

33 Anti-colonialist Declaration of the UN - General Assembly Resolution 1514 (XV), 14 Dec. 1960.

34 I.C. Henriques, A Herança Africana em Portugal - Séculos XV-XX (CTT Correios de Portugal, 2009).

35 J.Y. Loude, Lisboa, na Cidade Negra (Lisbon, 2005).

36 Mário Pinto de Andrade, Amilcar Cabral, Agostinho Neto and Alda Espírito Santo, amongst others, were some of these students coming from the colonies which later on became involved in the colonial resistance. See M.R. Sanches, 'Lisboa, capital do império: 
first contingent of Cape Verdean workers arrived, whose recruitment was intended to overcome the labour shortage resulting from the emigration of the Portuguese to Europe and from the military call-up for the colonial wars. It is estimated that around 100,000 Cape Verdean immigrants came to Portugal between 1963 and 1974, with the majority settling in Lisbon's peripheries. Even so, the percentage of Africans in Portugal remained small, accounting for only 1.5 per cent of total foreigners in $1960 .^{37}$ Coming from rural areas, mostly illiterate or with only basic schooling, they settled on the outskirts of the city, often in slums and selfbuilt neighbourhoods, and supplied the labour needed for the country's economic growth. ${ }^{38}$ Notwithstanding ideas of Luso-tropicalismo ${ }^{39}$ and racial and cultural equivalence, as imparted by the late propaganda of the Estado Novo regime, racial and class categorizations have subsequently been part of the deep social and spatial segregation visible in post-colonial Lisbon.

\section{Colonial legacies in the post-colonial global city}

In 1961, Salazar uttered the famous phrase that marked the beginning of the colonial war in Angola: 'To Angola, quickly and in force!'40 The colonial wars Portugal waged against the African independence movements spread to Guiné-Bissau (1963) and Mozambique (1964) and lasted until 1974, when the revolutionary movement led by middle-ranking officers in the Portuguese armed forces overthrew the regime on 25 April and embarked on negotiations that heralded the end of the conflicts and the beginning of independence. While they lasted, the colonial wars involved $1,368,900$ men and at least 8,831 died in combat. ${ }^{41}$ In the metropolis, the ivory tower that held the idea of exceptionality of Portuguese colonialism was finally toppled.

In 1975, thousands of, mostly white, Portuguese settlers arrived in Lisbon fleeing the growing political conflicts in Angola and Mozambique. They had headed to the African colonies, especially Angola and

Trânsitos, afiliações, transnacionalismos', in Domingos and Peralta (eds.), Cidade e Império, 279-318.

37 R.P. Pires, 'O regresso das colónias', in Bethencourt and Chaudhuri (eds.), História da Expansão Portuguesa, vol. V, 198-9.

${ }^{38}$ L. Batalha, 'Cabo-Verdianos em Portugal: comunidade e identidade', in P. Góis (ed.), Comunidade(s) Cabo-Verdiana(s): As Múltiplas Faces da Imigração Cabo-Verdiana (Lisbon, 2008), 25-36.

39 The term Luso-tropicalismo was coined by the Brazilian sociologist Gilberto Freyre and used to describe the exceptional nature of Portuguese colonialism: G. Freyre, O Mundo que o Português Criou (Lisbon, 1951).

40 A famous phrase by Salazar, on 13 Apr. 1961, uttered in a speech broadcast on Portuguese radio and television. F.R. de Meneses, Salazar. Uma Biografia Política (Lisbon, 2010), 507.

41 J.M. Ferreira, Portugal em Transe (1974-1985), in J. Mattoso (ed.), História de Portugal, vol. VII (Lisbon, 1994), 83, 87. 
Mozambique, just a few decades before. ${ }^{42}$ When they returned, these half million Portuguese were pejoratively called retornados ('returnees'). Many of them were crammed into Lisbon Airport, rescued by the air bridge established by the Portuguese government over these territories, or clustered on the quaysides in the port of Lisbon, where they also arrived by boat along with the few belongings they managed to salvage. The migrations to Africa and the colonial wars in the 1960s had already given a tangible dimension to the empire in the social life of the metropolis, but it was the end of Portuguese colonialism that definitively brought the reality of the empire to the very heart of the metropolis. This was a reality wrought from material and human remains, racial tensions, forms of colonial exploitation and political resentments brought by the returnees who came to Lisbon in 1975.

In the aftermath of the Revolution, the former imperial subjects also started to arrive; that is, the black people who had been regarded as indigenas in Guinea-Bissau, Angola and Mozambique until 1961. The first arrived as refugees, fleeing from civil wars that exploded in the former colonial territories, now independent countries, or from persecution justified by their collaboration with the colonial ruler. The revision of the Nationality Law in 1975, which had reserved Portuguese citizenship for individuals who could prove their European ancestry, largely excluded from Portuguese citizenship individuals belonging to other phenotypes and cultures. The former citizens of empire were now seen as a foreign, potentially immigrant, population. ${ }^{43}$ The migrant labourers from the Portuguese-speaking countries also started to arrive, especially during the 1980s, from Cape Verde, Angola and Guinea-Bissau. While in 1960 the proportion of Africans in the total number of foreigners in Portugal was only 1.5 per cent, by 1981 that figure reached 44 per cent. ${ }^{44}$ The independence of Mozambique in 1975 created a new wave of Indian migrants, who had moved there after the integration of Portuguese India into the Indian Union in 1961. Most of them were skilled middle-class Goans who held a Portuguese passport, but a group of Ishmaelites also came. The Ishmaelites developed a network of commercial interests, visible in areas of Lisbon such as the Avenue Almirante Reis, where they opened several furniture stores. ${ }^{45}$ With the worsening of the politicaleconomic situation in Mozambique, other groups of Indian migrants, including Hindus as well as Muslims, also departed for Portugal in

42 The white population in Angola stands at 324,000 individuals in 1973 - compared with 44,083 in 1940 - and in Mozambique at 190,000 individuals in 1973 - compared with 27,438 in 1940: C. Castelo, 'Colonial migration into Angola and Mozambique: constraints and illusions', in E. Morier-Genoud and M. Cahen (eds.), Imperial Migrations: Colonial Communities and Diasporas in the Portuguese World (Basingstoke, 2012), 137-56.

43 Decree Law 308-A, 24 Jun. 1975.

44 Pires, 'O regresso das colónias', 199.

45 J.M. Malheiros, 'Circulação migratória e estratégias de inserção local das comunidades católica goesa e ismaelita. Uma interpretação a partir de Lisboa', Lusotopie (2000), 377-98. 
1982-84. ${ }^{46}$ A Hindu community became established in Lisbon, mostly composed of people from the Indian state of Gujarat, and settled in metropolitan residential areas like Quinta da Vitória, as well as close to the city centre, in the Quinta da Holandesa neighbourhood of Areeiro. ${ }^{47}$

The imperial nationalistic policies were transformed after the empire's collapse in 1975. However, as in other former metropolises, the relations of domination and exploitation established under colonialism continued in many ways in post-colonial times and determined the nature of post-independence migration in Portugal, too. ${ }^{48}$ In the context of a political shift from an authoritarian colonialist regime to a democratic regime, the former categorizations of power and racialized representations that brought about deeply unequal relations in the colonial period were reformulated over time and came to guide social relationships, employment practices and everyday interaction systems that involved immigrants from former Portuguese colonies in Africa. For the most part, this population was employed in the construction industry or domestic service, and usually suffered from social exclusion. ${ }^{49}$ The expansion of the labour market in Portugal was encouraged by a period of relative economic growth, thanks to its membership of the European Union from 1986 and to the country's entry into the global market economy. Growth in the construction and public works sectors and the creation of new roles within Portuguese families, such as domestic service, fed the increasing demand for immigrant labour from Portugal's former colonies for unskilled jobs. ${ }^{50}$ These new immigrants settled in Lisbon's suburbs, in illegal dwellings and self-built neighbourhoods, around the areas created in the 1960s by internal labour migrations, further changing the social and racial morphology of the city. ${ }^{51}$ In Lisbon, these neighbourhoods, mostly inhabited by Afro-descendants, are areas of social marginality, labelled by the media as especially problematic. ${ }^{52}$ The Diário de Notícias, a major Portuguese newspaper, identified and described these neighbourhoods

46 Ibid.

47 R.A. Cachado, 'Locating Portuguese Hindus: transnationality in urban settings', Sociologia, Problemas e Práticas, 76 (2014), 109-24; N. Dias, Remigração e Etnicidade: Mobilidade Hindu no Trânsito Colonial entre a África de Leste e a Europa (Lisbon, 2016). According to Malheiros, in the early 1990s, there were 26,000 individuals of Indian origin in Lisbon: Malheiros, 'Circulação migratória, 389.

48 Of the 417,042 immigrants registered in 2012, almost half were from Portuguese-speaking countries (25.3\% Brazilian, 10.3\% Cape Verdean, 4.9\% Angolans, 4.3\% Guinean and 2.5\% Sao Tome) (Serviço de Estrangeiros e Fronteiras, 'Relatório de imigração, fronteiras e asilo', Público, 25 Jun. 2012, 6). The migrant population coming from these countries and Portuguese naturalized in the meantime must be added to these figures. The same source confirms the strong urban presence of immigration, especially in Lisbon, with nearly half the immigrants in Portugal $(181,901)$.

49 Pires, 'O regresso das colónias', 197-8.

50 J. Vasconcelos, 'Africanos e afrodescendentes no Portugal contemporâneo: redefinindo práticas, projetos e identidades', Cadernos de Estudos Africanos, 24 (2012), 15-23.

51 J.M. Malheiros, Imigrantes na Região de Lisboa. Os Anos da Mudança (Lisbon, 1997).

52 A.R. Alves, '(Pré) textos e contextos: media, periferia e racialização', Revista de Ciências Sociais E Trabalho, 44 (2016), 91-107. 
according to a racialist discourse associated with crime and violence: for example, the neighbourhood of Cova da Moura settled in 1977 by a largely Cape Verdean population is linked to a great deal of violent crime in Lisbon. Quinta do Mocho also emerged in the 1970s, mostly inhabited by immigrants from the former colonies, and is frequently the scene of disputes between rival gangs; while Bela Vista is a neighbourhood used to re-house refugees and immigrants from the former colonies in the 1980s and is noted for violent conflicts with the forces of authority. ${ }^{53}$ Once a metropolis, Lisbon became a global, increasingly cosmopolitan, city marked by social and material barriers between those who belong to it and those who are excluded, usually the poor and blacks. ${ }^{54}$

The landscape of the city also changed by other means. In the aftermath of 25 April and along with the change of street names linked to the regime, such as replacing Rua 28 de Maio by Rua 25 de Abril, there were also changes in the toponymy of Lisbon to reflect the reality of decolonization. In Lisbon, the Bairro das Colónias (District of the Colonies) was renamed Bairro das Novas Nações (District of the New Nations), and the Praça das Colónias became the Praça das Novas Nações in 1975, to honour the five new nations in the African continent (Guinea-Bissau, Mozambique, Cape Verde, São Tomé and Príncipe and Angola) and replace a nomenclature related to the Estado Novo and colonial rule. In 1983, Amílcar Cabral (founder of PAIGC) and Agostinho Neto (MPLA founder) both of whom had struggled for independence during the colonial wars, were also honoured in the toponymy of Lisbon. However, these toponymic changes were very limited and partial, as the colonial designations in the communes of the empire, such as Avenida Cidade de Lourenço Marques, Rua Cidade da Beira and Rua Vila Pery, amongst others, were largely preserved.

In terms of institutional semantics, the changes were more forceful, with public bodies and cultural institutions abandoning designations that referred back to colonial times and adopting more neutral and postcolonial-adjusted ones. ${ }^{55}$ This is how, for example, the Jardim e Museu Agrícola do Ultramar (Overseas Agricultural Museum and Garden) came to be renamed Jardim-Museu Agrícola Tropical (Tropical GardenMuseum of Agriculture), the Museu de Etnologia do Ultramar (Museum of Overseas Ethnology) changed its name to the Museu Nacional de Etnologia (National Museum of Ethnology), and the Instituto Superior de Ciências Sociais e Políticas Ultramarinas (Higher Institute of Social Sciences and Overseas Policies) shortened its name to the Instituto

53 Diário de Notícias, 26 Mar. 2010, 'Bairros de risco são base de tráfico e crime organizado, in http:/ / www.dn.pt/DNMultimedia/DOCS+PDFS/BAIRROS_PROBLEMATICOS.pdf, accessed 1 Sep. 2014.

54 M.R. Sanches, 'Lisboa pós-colonial e outras fortalezas da modernidade', Buala, http: //www.buala.org/pt/cidade/lisboa-pos-colonial-e-outras-fortalezas-na-modernidade, accessed 9 Feb. 2014.

55 João, 'Organização da memória', 392. 
Superior de Ciências Sociais e Políticas (Higher Institute of Social Sciences and Politics).

While the colonial was removed from the public life of the nation, it broke out in other, more visible ways in the daily life of Lisbon. Making use of the state support at their disposal to integrate into Portuguese society, many returnees opened businesses with names that referred directly to the colonial past. Pensão Luanda, Móveis Huíla and Stand Império are just a few examples of many names alluding to the colonial reality that christened many small businesses, such as cafes, grocery stores and hostels in Lisbon. The arrival of African populations also resulted in the emergence of new markets and goods, such as African cuisine restaurants.

The post-colonial period has also seen a different approach in the economic relations between Portugal and her ex-colonies. The presumption of a Portuguese-speaking citizenship resulting from the constitution in 1992 of a geographical area known as the Community of Portuguese Speaking Countries (CPLP), created on the basis of a principle of cultural and linguistic unity - Lusophony ${ }^{56}$ - gave rise to a specific cultural market, and it is not uncommon to see in stores references to the existence of Lusophone music, literature and food. Also, the new African elites, especially from Angola, are usually present in the most affluent parts of Lisbon, and an important segment of Lisbon's luxury stores depend on Angolan money. Angolan money is also behind the urban facades of banks and media enterprises. Working under an assimilationist rationale inherited from the colonial period, the structural asymmetries, the circumstances of social marginalization or deprivation experienced by most of the immigrants from former colonies and their descendants, the racial classifications, commonly expressed in subtle forms of racism that condition social relations, ${ }^{57}$ are rendered invisible through the prevalence of the Luso-tropicalist dominant discourse of peaceful co-existence with the racial and cultural difference.

\section{Identity politics and post-imperial branding}

It is also within Lisbon's public spaces that these discourses make their mark and new identity politics are devised, thereby updating ideas of race, class and community in relation to prevailing imperial ideologies. This is evident both in the territorialization of city space and in current urban development and regeneration processes. Old and run-down neighbourhoods in central Lisbon, such as in Mouraria, which became inhabited, from the 1980 s, by immigrant populations, ${ }^{58}$ were subjected to

${ }^{56}$ M. Cahen, 'Des caravelles pour le futur? Discours politique et idéologie dans $l^{\prime}$ institutionnalisation de la communauté des pays de langue portugaise', Lusotopie (1997), 391-433; A. Margarido, A Lusofonia e os Lusófonos: Novos Mitos Portugueses (Lisbon, 2001).

57 J. Vala (ed.), Novos Racismos: Perspectivas Comparativas (Linda-a-Velha, 1999).

58 J. Mapril, 'Um lugar estrutural? Legados coloniais e migrações globais numa rua em Lisboa', in Domingos and Peralta (eds.), Cidade e Império, 503-24. 
urban renewal schemes with the aim of having creative areas of social and cultural diversity emerging from the many national origins found there. The previous Luso-tropical myths have thus been updated and converted in a marketable interculturality, suitable for post-modern lifestyles and consumption patterns. ${ }^{59}$

Furthermore, the old imperial myths are still reproduced in the commemorative spaces of Lisbon, particularly those associated with the Portuguese seaborne empire, and are today extensively used by the tourism industry. In successive narratives poured into the space of the city, the foundational myths of the nation were reworked to accommodate the symbolic positioning of the country in a modern, multicultural and cosmopolitan Europe. As early as 1983, the Jerónimos Monastery and the Belém Tower, two national monuments inextricably linked to Portuguese maritime history, were inscribed on the UNESCO World Heritage list. UNESCO justified their inclusion because they are 'a reminder of the great maritime discoveries that laid the foundations of the modern world' ${ }^{60}$ In 1985, the bones of Fernando Pessoa, author of $A$ Mensagem, a literary work that deals with the glorious past of Portugal, were transferred to the cloister of the Jerónimos Monastery, again functioning as the primal stage for the enthronement of national heroes. Shortly afterwards, in 1986, the Treaty of Accession of Portugal to the European Union was signed in the Jerónimos Monastery. The old symbols of the imperial nation now served to place Portugal in the western European political arena. In this interpretation, Portugal became recognized as the country of the discoveries rather than as a former colonial centre. In 1993, the Belém Cultural Centre was inaugurated in the western wing of Praça do Império, where the Pavilion of the Portuguese in the World was located in the 1940 Exhibition. The new cultural facility was built to host the Portuguese presidency of the European Union in 1992, and once again places Belém as the centre of political power of the Portuguese nation. History is once again utilized to enshrine its symbolic value by designating the entity managing the facility as the Foundation of the Discoveries (Fundação das Descobertas). ${ }^{61}$

The enormous urban renovation undertaken in Lisbon for the 1998 World Expo can also be read in this light. Expo '98 redeemed the notion of Portugal's national history being linked to the sea and strongly alluded to the discoveries. But the discourse was updated by adopting the theme of 'Oceans' and relating it to contemporary issues of sustainable management and environmental protection. The aesthetics of the fair, the regeneration of the surrounding area, the construction of modern homes and services and

${ }^{59}$ N. Oliveira, 'Lisboa redescobre-se. A governança da diversidade cultural na cidade póscolonial. A scenescape da Mouraria', in Domingos and Peralta (eds.), Cidade e Império, 557602; A. Estevens, A Cidade Neoliberal (Lisbon, 2017).

$60 \mathrm{http} / /$ / whc.unesco.org/en/list/263, accessed 10 Jun. 2014.

${ }^{61}$ Bethencourt, 'A memória da expansão', 450; Peralta, 'A composição de um complexo de memória', 393. 
the functional layout of the site were combined with a powerful allusion to the country's imperial past. Once the Expo had finished, the site was named Parque das Nações (Park of Nations) and the streets named after Portuguese navigators or other imperial features. For example, a new theatre was called the Teatro Camões and the new bridge across the River Tagus at the north end of the Parque was christened the Vasco da Gama Bridge. The Sea (or Oceans) as the route to cultural encounters on a global scale and as a metaphor for a modern nation that is multifaceted and tolerant was converted into the chief rhetorical tool to locate Portugal in a new European identity space dominated by multiculturalism and cosmopolitanism. The watchwords of the new post-colonial rhetoric are tolerance and cultural contact, appropriate to the globalizing languages and branding operations of Portugality, linked to tourism, trade between Portugal and the former colonial territories and the designs of the so-called economic diplomacy. Gentrification, urban development and heritage management, all processes typical of post-modern consumption on the one hand, and of post-imperial nostalgia on the other, nourish an industry and a policy which is based on the heritagization of history. ${ }^{62}$ In this context, the wrongs of Portuguese colonialism, such as slavery, forced labour and colonial violence, are largely absent from political discourse and public view. ${ }^{63}$

\section{Conclusion: enduring mythologies and contested zones}

Lisbon is an observatory for a long and complex historical process that involves local, national and imperial communities, comprising specific institutions and relationships as well as the global dynamics. The analysis of the construction of an image of Lisbon as the capital of the empire and the urban process that go with it makes it possible to ground these dynamics in the complex social divisions of labour, the state regulations of everyday life and the powerful processes of social and racial stratification. At the same time, as Lisbon took on the features of an imperial city in the early twentieth century, there was increasing evidence of the clash between different social realities. Just as colonial modernity was accompanied by multiple processes of social stratification, so in the metropolis, too, urban modernity was accompanied by different levels of social and urban integration, with the increasing creation of urban zoning dynamics based on socio-economic categories.

62 I. Baucom, Out of Place: Englishness, Empire and the Locations of Identity (Princeton, 1999).

63 The speeches made during the Expo '98 opening that took place at the Portuguese parliament were all, from left to right, apologetic of Portuguese colonialism (despite some caution from the Socialist party compared with the discourse from the Social Democrat party. Assembleia da República, Sessão Comemorativa do V Centenário do Descobrimento do Caminho Marítimo para a Índia, AR, Lisbon, 15 Jun. 1998. 
It was not until the end of the colonial empire, with the overthrow of the regime in 1974, that evidence of the multiple rifts running through the imperial ideology was finally brought to the capital, with the arrival in Lisbon of thousands of returnees and demobilized troops from the colonies. Even so, in a period of deep political upheaval, the theme of Portuguese colonialism comes lower down on an agenda marked by the ideological polarization of the country. The transition to the post-colonial was only signalled by the steady arrival of immigrants from the former African colonies. They were mostly absorbed by domestic work and the construction sector and settled on the outskirts of the metropolis in selfbuilt neighbourhoods where phenotype and poverty were the dominant social markers. The post-colonial social landscape is thus intersected by power relations and forms of categorization, which, although not exclusively a colonial legacy, nonetheless relate to obvious continuities with the colonial period.

Imperial mythologies also came to be rehabilitated in the democratic era, with public and political culture making use of the old myths of the 'golden era' of the discoveries to negotiate the symbolic place of Portugal in the new European identity space, as it made its way into the realm of consumerism and commodification. The myths of the empire woven by successive regimes continued to structure national consciousness, persisting in ways of thinking and acting, in politics, the economy and everyday life, influencing models of governance and social relationships. A prolonged silence on the wrong-doings of Portuguese colonialism persisted over decades and only very recently an open discussion on the nation's colonial past has been put forward, especially in Lisbon. A good example involves the city council's controversial proposal, met by public resistance, to remove the coats-of-arms flower beds representing the provinces and districts of Portugal from the Praça do Império installed there in the 1960s. Whilst its opponents argued that it would constitute an attack on the historical heritage of the nation, many supporters welcomed the initiative, believing that it would break with a persistent colonialist narrative. A number of museum exhibitions also raised objections: the Museu de Arte Antiga's exhibition 'The Global City', which portrayed Lisbon as an old multicultural urban centre, generated fierce debate in newspapers; whilst the exhibition 'Racisms', organized by the city council and curated by the historian Francisco Bethencourt at the Padrão dos Descobrimentos, was one of the first efforts to counter the effect of Belém's ideological landscape. More recently, the inauguration at the Largo da Misericórdia of a statue dedicated to missionary priest António Vieira (1608-97), who despite his defence of the Brazilian indigenous populations was less critical when it came to African slavery, also led to public discussion. Some scholars, journalists, activists, artists and intellectuals have been engaged in claiming the historical truth of Portuguese colonialism, appealing for a recognition of those facets 
that contradict the supposed goodness of the Portuguese colonial project, including slavery, forced labour, colonial wars and even the repatriation of settlers to the former metropolis at the time of African decolonization. ${ }^{64}$

The emergence of this public discussion about the empire's memory, which is also an arena for discussing Lisbon's memory, has been accompanied by the denunciation of the social situation experienced by migrants and Portuguese of African descent in Lisbon's urban fabric. Class disadvantage has been reinforced by the prevailing effect of various types of racism. However, having contributed to change the organization of the city's space, and by intervening in the social space through practices and representations, these populations have tried to find their place in the city. ${ }^{65}$ Cape Verdeans, Guineans, Angolans and Brazilians crisscross cultural elements, both Portuguese and non-Portuguese, to negotiate new symbolic and class positionings in the city. ${ }^{66}$ Here, notions like creolage and Luso-tropicality are often invoked in the city's daily life and exchanged between immigrants and locals in the process of assigning meaning to the colonial past and the post-colonial present. This exchange and the identity clashes that often ensue lead to the constant redefinition of the categories of 'us' and 'other', here and there, past and present, local and global, within and across the city space. ${ }^{67}$

64 These claims reached unprecedented proportions following the statements made by the president of the Portuguese Republic during his state visit to Senegal in Apr. 2017 on the alleged pioneering role of Portugal in the abolition of slavery.

65 F.L. Machado, 'Etnicidade em Portugal. Contrastes e politização', Sociologia Problemas e Práticas, 12 (1992), 123-36.

66 S. Frangella, 'Fomos conhecer um tal de Arroios: construção de um lugar na imigração brasileira em Lisboa', in Domingos and Peralta (eds.), Cidade e Império, 463-502.

67 D. Massey, Space, Place and Gender (Minneapolis, 1994). 